\title{
Can export of organic matter from estuaries support zooplankton in nearshore, marine plumes?
}

\author{
Aquatic Ecology 2009: 383 - 393
}

\author{
Thomas A. Schlacher ${ }^{1^{*}}$, Rod M. Connolly ${ }^{2}$, Anna J. Skillington ${ }^{1 \#}$, Troy F. Gaston ${ }^{1 \$}$ \\ ${ }^{1}$ Faculty of Science, Health \& Education, University of the Sunshine Coast, Maroochydore DC, QLD- \\ 4558, Australia. \\ ${ }^{2}$ Australian Rivers Institute - Coast and Estuaries, and School of Environment, Griffith University, \\ Gold Coast campus, Queensland, 4222, Australia; r.connolly@griffith.edu.au \\ *corresponding author: T.A. Schlacher; tschlach@usc.edu.au \\ \# present address: Port of Townsville, PO Box 1031, Townsville, QLD-4810, Australia. \\ askillington@townsville-port.com.au \\ \$present address: Australian Maritime College, PO Box 986, Launceston, Tasmania 7250, Australia; \\ T.Gaston@amc.edu.au
}

\begin{abstract}
Marine and terrestrial ecosystems are connected via transfers of nutrients and organic matter in river discharges. In coastal seas, such freshwater outflows create prominent turbidity plumes, which are areas of high biological activity in the pelagos, of which zooplankton is a key element. Conceptually, the increased biomass of zooplankton consumers in plumes can be supported energetically by two alternative trophic pathways: (1) marine phytoplankton stimulated by riverine nutrients, or (2) direct trophic subsidies through the uptake of terrestrial and estuarine organic matter flushed to sea. The relative importance of these two pathways has not previously been established. Isotopic tracing (carbon and nitrogen) was used to measure the extent of incorporation of marine versus terrestrial matter into mesozooplankton consumers in the plumes off a small estuary in eastern Australia. Replicate zooplankton samples were taken during baseflow conditions with minimal freshwater influence to the sea, and during pulsed discharge events that generated turbidity plumes in coastal waters. Food sources utilised by zooplankton differed among locations and with the strength of freshwater flow. Terrestrial and estuarine carbon only made a sizeable contribution (47\%) to the carbon demands of zooplankton in the lower estuary during pulsed freshwater flows. By contrast, in plumes in nearshore marine waters, phytoplankton supplied up to $90 \%$ of the diet of zooplankton feeding in the plumes. Overall, it was 'fresh' carbon, fixed by marine phytoplankton, the growth of which became stimulated by fluvial nutrient exports, that dominated energy flows in plume regions. The trophic role of terrestrial and estuarine organic exports was minor. The trophic dynamics of plankton in small coastal plumes is closely linked to variations in freshwater flow, but this coupling operates mainly through the enhancement of in-situ phytoplankton production rather than cross-boundary transfers of organic matter to marine food webs in the pelagos.
\end{abstract}

Key Words: land-ocean coupling, plumes, trophic subsidy, stable isotope, food webs 


\section{Introduction}

Production in estuaries can outstrip internal consumption and storage. Excess organic matter thus becomes available for export to coastal seas where it stimulates marine productivity - this is the central prediction of the outwelling hypothesis (sensu Odum et al. 1979). Discharges of major rivers to coastal seas are the most striking example of material transfers and outwelling in the context of land-ocean coupling. The fundamental driver of this coupling is river discharge, and estuaries act as conduits for the delivery of large amounts of fluvial sediments, organic matter and nutrients to coastal seas (Milliman and Meade 1983). Here, low-salinity waters form buoyant turbidity plumes that are rich in nutrients and generate hot spots of biogeochemical and biological activity on the continental shelf (McKee et al. 2004).

The key tenets of outwelling and land-ocean coupling require the transfer of organic matter and nutrients across ecosystem boundaries and its subsequent incorporation by organisms in the receiving ecosystem. Plume regions receive and process the bulk of the terrestrial and estuarine matter advected to coastal seas, and are amongst the most productive areas of the world's oceans (Dagg and Breed 2003; McKee et al. 2004). Thus, marine organisms in plumes are energetically coupled to nutrients and organic matter supplied from the land and estuaries.

Increased biological activity in plume regions is generally most evident in planktonic ecosystem components. Nutrients exported in river discharges stimulate phytoplankton growth (Lohrenz et al. 1999; Liu and Dagg 2003), creating concentrations of phytoplankton biomass in plume and frontal waters (Mallin et al. 2005). Similarly, elevated densities of zooplankton, including larval fish, are typical of plume regions (Grimes and Kingsford 1996; Dagg et al. 2004). Zooplankton can exert strong top-down control on primary production in plume waters, grazing a substantial fraction (up to 86\%) of daily production (Liu and Dagg 2003); this makes zooplankton a key energetic link in the food web of plumes (Breed et al. 2004). Significantly, zooplankton in plumes can have a catholic diet that mirrors available resources and includes detritus (Turner and Tester 1989); consumption of terrestrial and estuarine material is therefore possible.

Because plumes both support enhanced production of marine phytoplankton stimulated by riverine nutrients, and contain organic matter flushed from estuaries, zooplankton consumers in plumes can access two alternative sources of carbon: (1) organic matter of terrestrial and estuarine provenance, and (2) fresh production by marine phytoplankton (Fig. 1). Thus, zooplankton production in plume areas can be supported via a trophic pathway linked directly to the incorporation of terrestrial matter or via the assimilation of fresh carbon fixed by marine producers following nutrient stimulation (Fig. 1). Alternatively, zooplankton nutrition can be a composite of feeding directly on terrestrial organic matter as well as grazing on marine phytoplankton; in this case, terrestrial and marine sources would supply varying proportions to the total carbon demands of the consumers. Although phytoplankton dynamics and grazing by zooplankton are documented for plumes (Liu and Dagg 2003; Wysocki et al. 2006), the role of direct trophic subsidies (sensu Polis et al. 1997) in the form of terrestrial and estuarine organic matter is unknown. Therefore, the primary objective of this study was to determine the relative contribution of marine versus terrestrial organic matter sources to mesozooplankton consumers in plumes. 


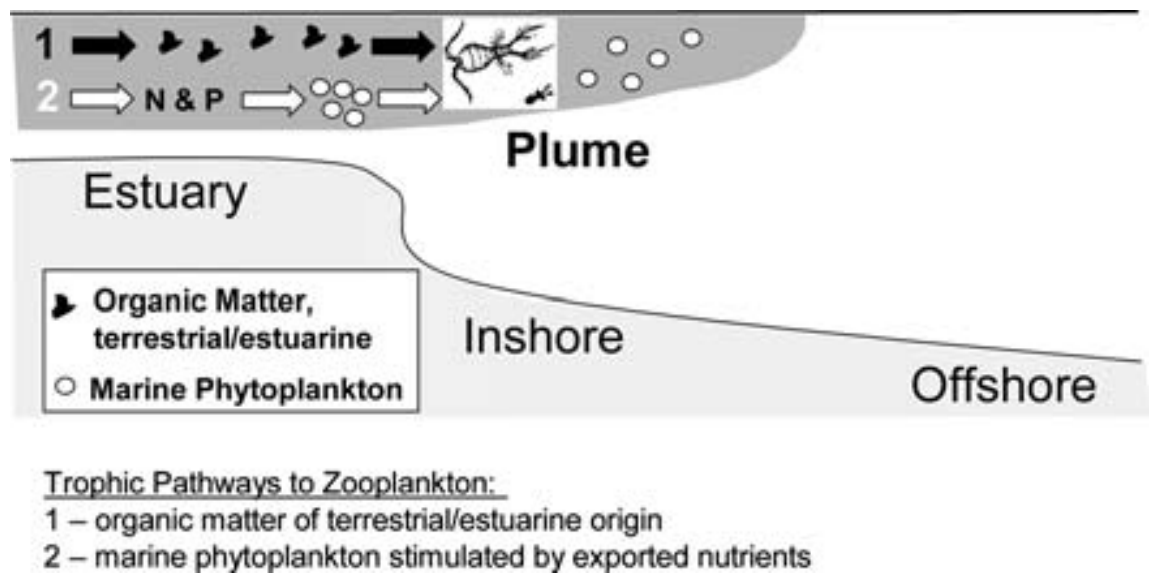

Fig. 1 Conceptual model of trophic pathways supporting zooplankton consumers in river plumes in nearshore marine regions.

Stable isotope analysis has become the principal method for identifying pathways of organic matter and nutrient transfers in aquatic ecosystems (Fry 2006). The most common applications include the reconstruction of animal diets, delineation of food web architectures, and the tracing of organic matter transfers amongst food web components, spanning freshwater (Bunn et al. 2003), estuarine (Schlacher and Wooldridge 1996; Connolly et al. 2005) and marine domains (Polunin et al. 2001; Grall et al. 2006).

Carbon and nitrogen produced on land or in freshwater systems are highly mobile and their incorporation into estuarine food webs can be measured efficiently via isotopic tracing (Fry 1999; Wissel and Fry 2005), as is the case for the export and trophic fate of this material when it enters shallow coastal seas (Darnaude et al. 2004). Such isotopic tracing of energy transfers across ecosystem boundaries is mainly based on isotopic differences in source materials according to the site of their production. For carbon, distinct terrestrial and estuarine signatures result from differences in photosynthetic pathways and inorganic carbon sources (Peterson and Fry 1987), whereas human modifications of nitrogen pools in coastal watersheds impart a distinct isotopic signal to the nitrogen exported to estuarine and marine systems (McClelland et al. 1997; Schlacher et al. 2005).

Here we exploit differences in isotopic signatures between terrestrial/estuarine and marine organic matter to distinguish between the two alternative trophic pathways that can support zooplankton in plumes (Fig. 1). The expectation is that nearshore zooplankton subjected to freshwater discharge would differ in their isotopic signatures from marine counterparts outside the area of freshwater influence, provided that they assimilate substantial amounts of organic matter of terrestrial and estuarine provenance (Pathway 1, Fig. 1). Alternatively, if marine phytoplankton is the principal carbon source for zooplankton consumers in regions subjected to river discharge, isotopic signals of zooplankton should be indistinguishable from those in offshore regions, signalling a low importance of outwelled organic matter to plume consumers (Pathway 2, Fig. 1). This study thus determines whether organic matter flushed into the nearshore zone or marine phytoplankton stimulated by exported nutrients is the principal energy source for zooplankton in plumes.

\section{Methods}

\subsection{Study site}

We identified zooplankton dietary sources in a nearshore plume generated by a small estuary, the Mooloolah, located on the east coast of Australia $\left(153^{\circ} 07^{\prime} \mathrm{E}, 26^{\circ} 41^{\prime} \mathrm{S}\right)$. Details 
of the study site and estuary are provided by Gaston et al. (2006). Briefly, it is a shallow and short estuary (depth $1-5 \mathrm{~m}$, tidal reaches $13 \mathrm{~km}$ ) that drains a small catchment $\left(194 \mathrm{~km}^{2}\right)$ of high relief over a narrow $(<50 \mathrm{~km})$ coastal strip. The estuary discharges through an artificially trained entrance onto a high-energy, exposed coastline. Heavy rainfall results in strongly pulsed freshwater discharge that generates prominent turbidity plumes off the estuarine entrance. These plumes are constrained within $1 \mathrm{~km}$ off the coastline and last for several days to weeks depending on discharge volumes (Gaston et al. 2006). We sampled two sites influenced directly by freshwater discharge, one in the lower estuary and one $1 \mathrm{~km}$ off the entrance where plumes develop, plus a marine reference station $3 \mathrm{~km}$ offshore which fell well outside the direct influence of plumes (Gaston et al. 2006).

Plume development is driven by rainfall events in the catchment and rainfall is seasonally bimodal, alternating between mostly dry winters and wet summers. We aimed to encompass the full annual spectrum of flow regimes, and therefore sampled three distinct plume phases (1): baseflows conditions (Aug. - Nov. '03), (2) freshets that moved through the estuary in early Dec. '03 and Feb. '04, and (3) residual plumes from Dec. to Feb. '04 (Fig. 2a). Temporal replication during low discharge periods was at $14 \mathrm{~d}$ intervals, increasing to targeted collections within $24 \mathrm{~h}$ of heavy rainfall events and 2-7 d intervals in the post-event phase (Fig. 2a).

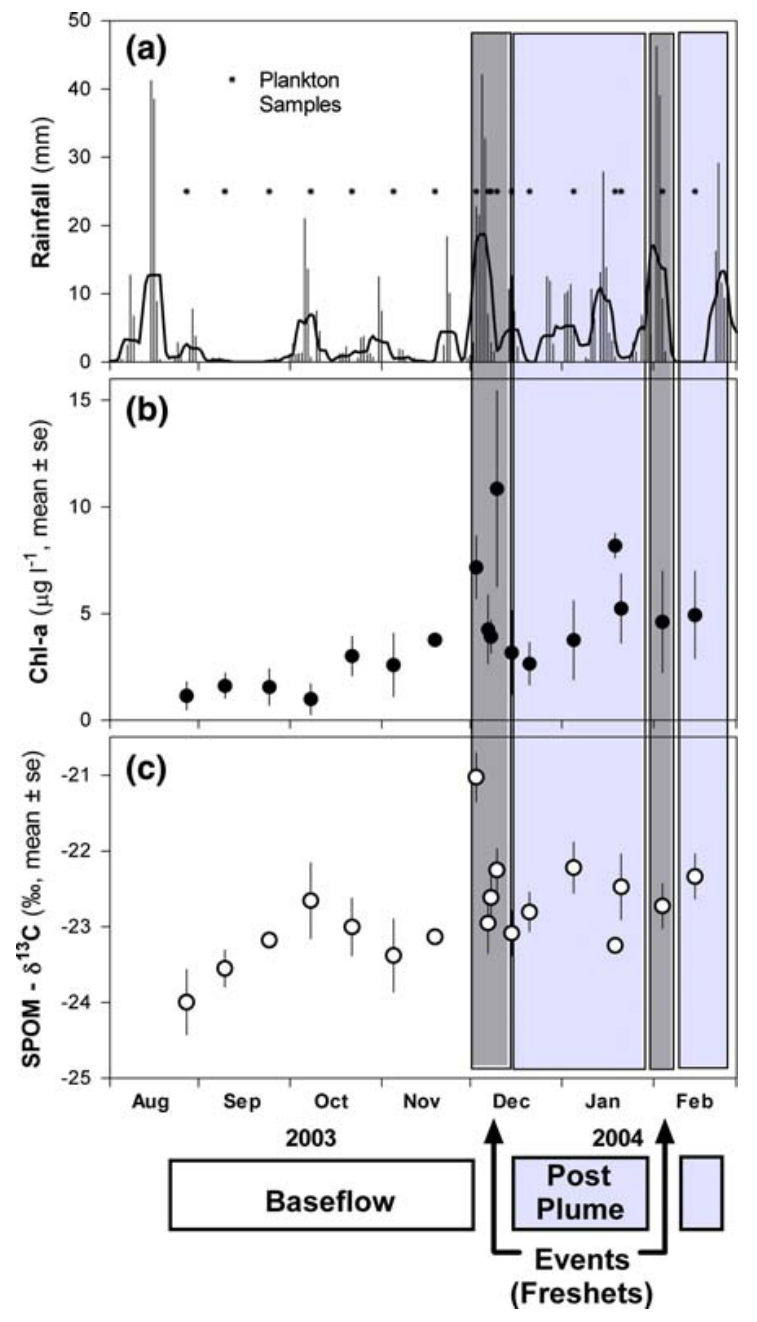

Fig. 2 Variation in a) rainfall in the watershed and corresponding changes in b) chlorophyll-a and c) carbon isotope signature of the organic fraction of suspended particles (SPOM) in the lower estuary and the plume region off the estuarine mouth. 


\subsection{Field sampling}

Mesozooplankton was collected with WP2-nets $(200 \mu \mathrm{m}$ mesh, mouth diameter $0.5 \mathrm{~m}$, cone length $2.6 \mathrm{~m}$ ), fitted with General Oceanics flowmeters (model 20/30R). Duplicate horizontal tows were made at night with a small boat at 3-4 knots, towing against ebb currents in surface $(0-0.6 \mathrm{~m})$ and subsurface $(2 \mathrm{~m}$ in estuary and $5 \mathrm{~m}$ outside the estuary) layers. uspended particulate organic matter (SPOM) was obtained with a Niskin bottle from the same depths, and concentrated on pre-combusted $\left(450^{\circ} \mathrm{C}, 24 \mathrm{~h}\right) \mathrm{GF} / \mathrm{C}$ filters (nominal pore size $0.45 \mu \mathrm{m}$ ). All samples were immediately placed on ice and processed within 12 of collection. Prior to each plankton tow, CTD casts were made with a Hydrolab Datasonde 4a, fitted with a submersible fluorometer.

\subsection{Laboratory processing}

Stable carbon and nitrogen isotope ratios were measured in five distinct size classes of the mesozooplankton. Size fractionation was done by washing the chilled bulk samples through a nested series of 10 sieves with mesh sizes of $200,300,355,425,500,600,710,850$, 1000 and $2000 \mu \mathrm{m}$. From the resulting fractions we selected five size ranges $(200-300 \mu \mathrm{m}$, $355-425 \mu \mathrm{m}, 500-600 \mu \mathrm{m}, 710-850 \mu \mathrm{m}$, and 1000-2000 $\mu \mathrm{m}$ ) separated from other fractions by size intervals of $55-250 \mu \mathrm{m}$. Larger detritus particles were removed by screening samples under a stereo microscope.

Stable isotope ratios were measured in the Isotope Analytical Facility of Griffith University on an automated Isoprime Isotope-Ratio Mass Spectrometer. Stable isotope ratios are expressed in \%o using the conventional delta $(\delta)$ notation: $\delta \mathrm{X}(\%)=\left[\left(\mathrm{R}_{\text {sample }} / \mathrm{R}_{\text {standard }}\right)-1\right] \mathrm{X}$ 1000; where $X$ is $\delta^{13} \mathrm{C}$ or $\delta^{15} \mathrm{~N}$, and $\mathrm{R}$ is the ${ }^{15} \mathrm{~N} /{ }^{14} \mathrm{~N}$ (nitrogen) or ${ }^{13} \mathrm{C} /{ }^{12} \mathrm{C}$ (carbon) ratio in the sample and standards (Vienna PDB for carbon and the IAEA international standard of atmospheric $\mathrm{N}_{2}$ for nitrogen).

\subsection{Data analysis}

We measured dual isotopes ratios (i.e. $\delta^{13} \mathrm{C}$ and $\delta^{15} \mathrm{~N}$ ) in the same zooplankton samples fractioned by size, and isotope ratios of the two elements were therefore treated as multiple dependent variables. Isotope ratios were thus tested using a multivariate analysis of variance (MANOVA). The MANOVA model included three main terms: 1) site (estuary, mouth, ocean), 2) plume phase (baseflow, event, residual plumes) and 3) zooplankton size fraction (200-300, 355-425, 500-600, 710-850, and 1000-2000 $\mu \mathrm{m})$. Because our a priori predictive model stated that sites influenced by river discharge (i.e. estuary and mouth) would differ from the oceanic reference station only during times of significant freshwater flow and not during baseflow conditions, the main test of interest was the phase $x$ site interaction term. The MANOVA was complemented by two-factor ANOVAs calculated separately for carbon and nitrogen ratios to assess whether significant interaction terms were consistent among elements.

The contribution of terrestrial versus marine carbon to zooplankton diets was calculated with a two-source isotope mixing model (Phillips and Gregg 2001). We used as marine endmembers $\delta^{13} \mathrm{C}$ values of SPOM collected at the ocean reference station $(\bar{x}=-21.93 \%$, $\mathrm{se}=1.40, \mathrm{n}=22$ ), and as terrestrial/estuarine endmembers SPOM samples from the oligohaline, uppermost reaches of the estuary $(\bar{x}=-26.35 \%$, se $=1.28, n=21)$. Trophic fractionation $(\Delta \delta 13 C)$ was set at $+1.3 \%$ (DeNiro and Epstein 1978). Because we analysed a broad size range of plankton consumers, trophic modes are likely to encompass both primary grazers and predators, and we therefore used a trophic position of 1.5 levels above phytoplankton in the isotope mixing models. 


\section{Results}

\subsection{Environmental conditions}

Fluctuations in rainfall intensity in the watershed resulted in substantial changes to physicochemical conditions, phytoplankton biomass and isotopic signatures of suspended particles in the lower estuary and off the estuary mouth (Fig. 2). Strong rainfall events in early Dec 2003 and early Feb 2004 created pulses of freshwater discharge that moved as freshets through the estuary and initiated the development of prominent turbidity plumes off the estuarine entrance. The plume region had a limited spatial extent, being constrained to within $1500 \mathrm{~m}$ of the shore, and low-salinity water masses were generally confined to the top 2-3 m of the water column. Freshets reduced salinity to as low as $6.84 \mathrm{psu}$, but salinity levels recovered close to baseflow conditions within days, and were only marginally lower in plume waters following the events (Table 1, Fig. 2). Freshwater flows exported riverine sediments: turbidity levels spiked at 38 NTU during freshets, and mean event concentrations $(\overline{\mathrm{x}}=12.7 \mathrm{NTU})$ were an order of magnitude higher compared with baseflows $(\overline{\mathrm{x}}=1.2 \mathrm{NTU})$; turbidity levels abated after the events but remained slightly elevated at $\bar{x}=3.4$ NTU (Table 1).

Table 1 Summary of environmental variables and isotopic signatures of suspended particulate organic matter (SPOM) in the lower estuary and mouth region during different phases of plume development.

\begin{tabular}{|c|c|c|c|c|c|c|c|c|c|}
\hline & \multicolumn{3}{|c|}{$\begin{array}{c}\text { Baseflow } \\
(n=24)\end{array}$} & \multicolumn{3}{|c|}{$\begin{array}{l}\text { Event (Freshet) } \\
\quad(n=14)\end{array}$} & \multicolumn{3}{|c|}{$\begin{array}{l}\text { Post Plume } \\
\quad(n=24)\end{array}$} \\
\hline & $\bar{x}$ & (min. & $\max )$. & $\bar{x}$ & $(\min$. & $\max )$. & $\bar{x}$ & $(\min$. & max.) \\
\hline Salinity (psu) & 35.9 & (32.7 & $36.5)$ & 29.1 & $(6.8$ & 36.3) & 33.6 & $(24.1$ & 36.4) \\
\hline Turbidity (NTU) & 1.2 & $(<0.1$ & 7.3) & 12.7 & $(<0.1$ & $38.0)$ & 3.4 & $(<0.1$ & $9.0)$ \\
\hline Chl-a $\left(\mu \mathrm{g} \mathrm{I}^{-1}\right)$ & 2.0 & $(<0.1$ & 5.4) & 4.1 & $(<0.1$ & 11.3) & 5.8 & $(<0.1$ & 21.4) \\
\hline SPOM- $\delta^{13} \mathrm{C}(\%)$ & -23.3 & $(-25.0$ & $-21.4)$ & -22.6 & $(-23.8$ & $-21.3)$ & -22.5 & $(-23.7$ & $-20.7)$ \\
\hline SPOM- $\delta^{15} \mathrm{~N}(\%)$ & 4.7 & (0.9 & $9.0)$ & 0.6 & $(-5.5$ & 4.1) & 3.6 & $(0.4$ & $8.5)$ \\
\hline
\end{tabular}

Freshwater flows changed both the amount and isotopic signatures of putative food sources available to zooplankton consumers in nearshore waters (Table 1, Fig. 2). Discharge events produced spikes in chl-a concentrations up to $21.4 \mathrm{mg} \mathrm{I}^{-1}$, with mean event concentrations $\left(\bar{x}=4.1 \mu \mathrm{g} \mathrm{I}^{-1}\right)$ doubling from baseflow values $\left(\bar{x}=2.0 \mu \mathrm{g} \mathrm{I}^{-1}\right)$. After the freshets, phytoplankton biomass remained three-fold higher than during low freshwater flows at $\overline{\mathrm{x}}=5.8 \mathrm{\mu g} \mathrm{I}^{-1}$ (Table 1, Fig. 2). Carbon isotope ratios of the organic fraction in suspended particles (SPOM) became enriched by $+0.7 \%$ during freshets and remained at these values post-plume (Table 1). Freshwater pulses also produced marked shifts in nitrogen isotopic signatures of SPOM: mean event values of SPOM- $\delta^{15} \mathrm{~N}$ were enriched by $\sim 4 \%$ over both baseflow values and nitrogen ratios measured in SPOM collected in the weeks after the events (Table 1). Changes in key environmental attributes of the water column and isotopic signature of SPOM related to plume development were more distinct during first freshet (Dec.) compared to weaker responses during the second freshet (Feb.) measured during the study. 
Table 2 Summary of Multivariate Analysis of Variance (MANOVA) complemented by univariate ANOVAs for individual elements, contrasting isotopic signatures of zooplankton amongst size classes, sites (i.e. estuary, mouth, ocean) and plume phases (i.e. baseflow, event, post plume). Because our predictive model stated that spatial differences depend on flow regimes, the chief test of interest is the Site $x$ Phase interaction term (highlighted).

\section{A - MANOVA}

\begin{tabular}{lccccc} 
& $\begin{array}{c}\text { Wilk's } \\
\text { Lambda }\end{array}$ & F & Effect df & Error df & p \\
\cline { 2 - 6 } Size Class & 0.895 & 5.25 & 8 & 736 & $<0.001$ \\
Site & 0.843 & 16.35 & 4 & 736 & $<0.001$ \\
Phase & 0.784 & 23.79 & 4 & 736 & $<0.001$ \\
Size Class x Site & 0.970 & 0.70 & 16 & 736 & 0.797 \\
Size Class x Phase & 0.951 & 1.17 & 16 & 736 & 0.286 \\
* Site x Phase & 0.862 & 7.10 & 8 & 736 & $<0.001$ \\
Size Class x Site x Phase & 0.939 & 0.73 & 32 & 736 & 0.864 \\
\hline
\end{tabular}

\begin{tabular}{lccccc} 
B - ANOVA & \multicolumn{2}{c}{$\delta^{13} \mathbf{C}$} & \multicolumn{2}{c}{$\delta^{15} \mathbf{N}$} \\
Size Class & $\mathbf{d f}$ & $\mathbf{F}$ & $\mathbf{P}$ & $\mathbf{F}$ & $\mathbf{P}$ \\
\cline { 2 - 7 } Site & 4 & 3.72 & 0.006 & 5.61 & $<0.001$ \\
Phase & 2 & 24.73 & $<0.001$ & 6.70 & 0.001 \\
Size Class x Site & 2 & 19.06 & $<0.001$ & 30.23 & $<0.001$ \\
Size Class x Phase & 8 & 0.90 & 0.519 & 0.48 & 0.872 \\
* Site x Phase & 8 & 1.65 & 0.110 & 0.52 & 0.842 \\
Size Class x Site x Phase & 4 & 7.31 & $<0.001$ & 6.83 & $<0.001$ \\
\hline Error & 16 & 1.10 & 0.357 & 0.41 & 0.979 \\
\hline
\end{tabular}

\subsection{Zooplankton isotopes}

Pulsed freshwater inflows significantly changed the isotopic signatures of zooplankton consumers in areas influenced by river discharge (Table 2; Fig. 3). During freshets, zooplankton in both the plume area and the lower estuary differed significantly in $\delta^{13} \mathrm{C}$ from zooplankton collected at the offshore site not influenced by river discharges (Table 3). At this time, carbon isotope values of consumers in the lower estuary shifted towards more negative values, indicating uptake of a greater fraction of estuarine and terrestrial material. In the mouth area, carbon isotopes become more enriched compared to the oceanic reference site, suggesting carbon uptake from fresh organic matter produced by marine phytoplankton stimulated by the estuarine discharge. During baseflow conditions, only the carbon isotope values of zooplankton in the lower estuary differed from those of the reference site. After the freshets had passed, significant spatial differences in $\delta^{13} \mathrm{C}$ were limited to the mouth (Table 3; Fig. 3). Nitrogen isotope ratios $\left(\delta^{15} \mathrm{~N}\right)$ showed no significant spatial contrasts between sites during baseflow conditions and freshets, but became significantly more enriched in both the lower estuary and the mouth region after the flow events (Table 3, Fig. 3). Isotopic contrasts between sites and plume phases were generally consistent amongst size classes of consumers (MANOVA; Interaction Term - Site $x$ Phase $x$ Size: Wilk's Lambda $=0.94, \mathrm{P}=0.86$ ), although smaller plankton became more strongly depleted in ${ }^{13} \mathrm{C}$ during freshets in the lower estuary (Fig. $4 \mathrm{~b}$ ). 


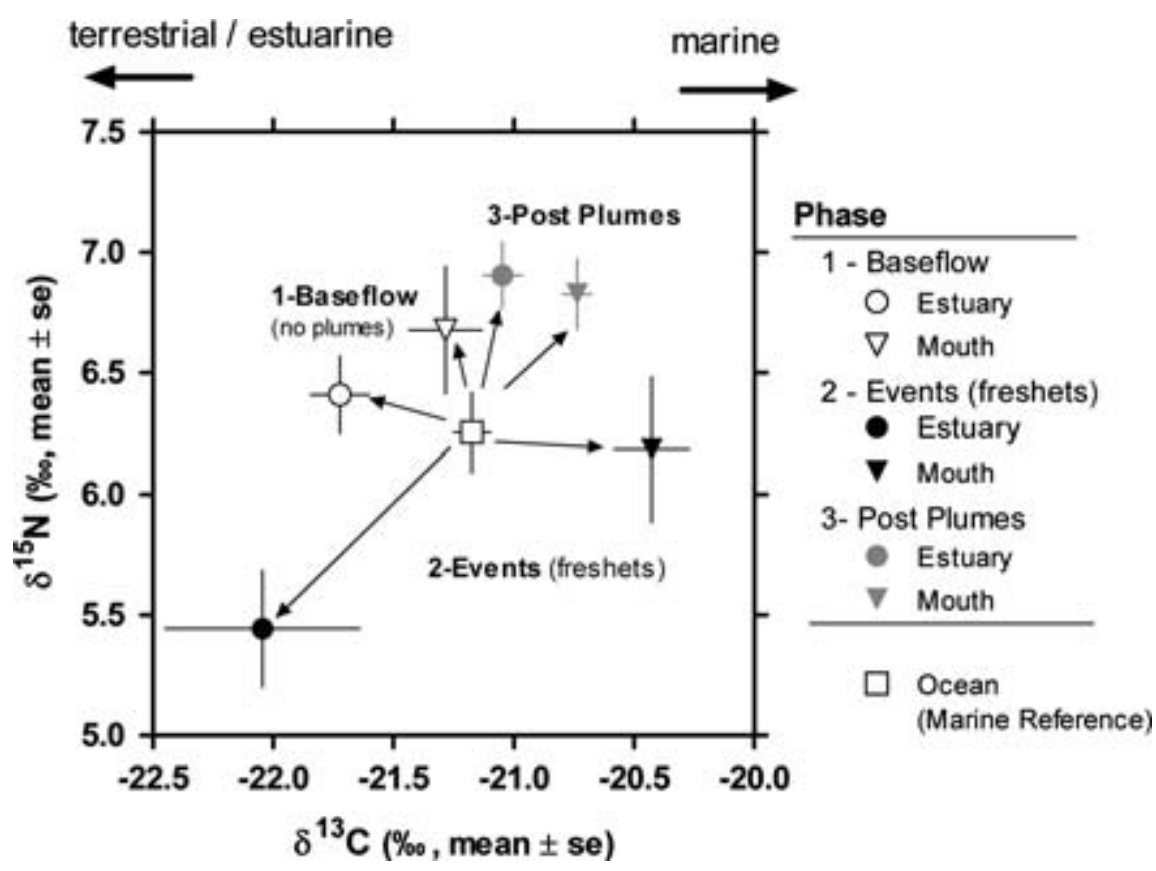

Fig. 3 Spatial contrasts in carbon and nitrogen isotope ratios of zooplankton between an offshore reference station and the lower estuary and off the estuarine mouth, during three phases of plume development (cf. Fig. 2).

Table 3 Probability values from SNK post-hoc testing for spatial contrasts in isotope signals in zooplankton between the ocean reference site and the lower estuary and mouth region during three phases of freshwater flow and plume strength (cf. Fig. 2).

\begin{tabular}{lccccc} 
& & \multicolumn{2}{c}{$\delta^{13} \mathrm{C}$} & \multicolumn{2}{c}{$\delta^{15} \mathrm{~N}$} \\
Phase & & Estuary & Mouth & Estuary & Mouth \\
\hline 1 - Baseflow & Ocean vs. & 0.002 & 0.489 & 0.581 & 0.293 \\
2 - Event (freshet) & Ocean vs. & 0.001 & 0.005 & 0.075 & 0.852 \\
3 - Post Plume & Ocean vs. & 0.285 & $<0.001$ & 0.021 & 0.018 \\
\hline
\end{tabular}

Carbon sources utilised by zooplankton differed among locations and hydrological phases (Table 4). Terrestrial and estuarine carbon made a sizeable contribution (39\%) to carbon demands of zooplankton consumers in the lower estuary during baseflows, and this rose to $47 \%$ during freshets. Thus, consumers in the lower estuary could meet about half of their carbon demands by feeding on organic matter transported downstream during flow events. By contrast, during baseflow conditions, zooplankton in the plume region off the estuary mouth relied slightly more on marine carbon (Table 4). The trophic pathway underpinned by marine phytoplankton production became dominant during freshets and subsequent plumes when zooplankton in nearshore waters derived $83-90 \%$ of its carbon from marine sources (Table 4). Overall, the carbon supply to zooplankton in the plume region was from 'fresh' carbon, fixed by marine phytoplankton whose growth was stimulated by fluvial nutrient exports. Conversely, the trophic role of terrestrial and estuarine production was generally smaller, being most evident inside the estuary during freshets. 

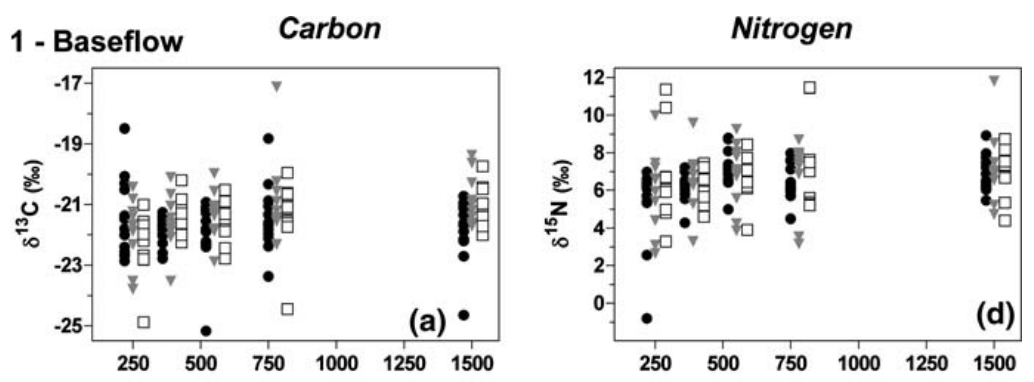

2 - Event (freshet)
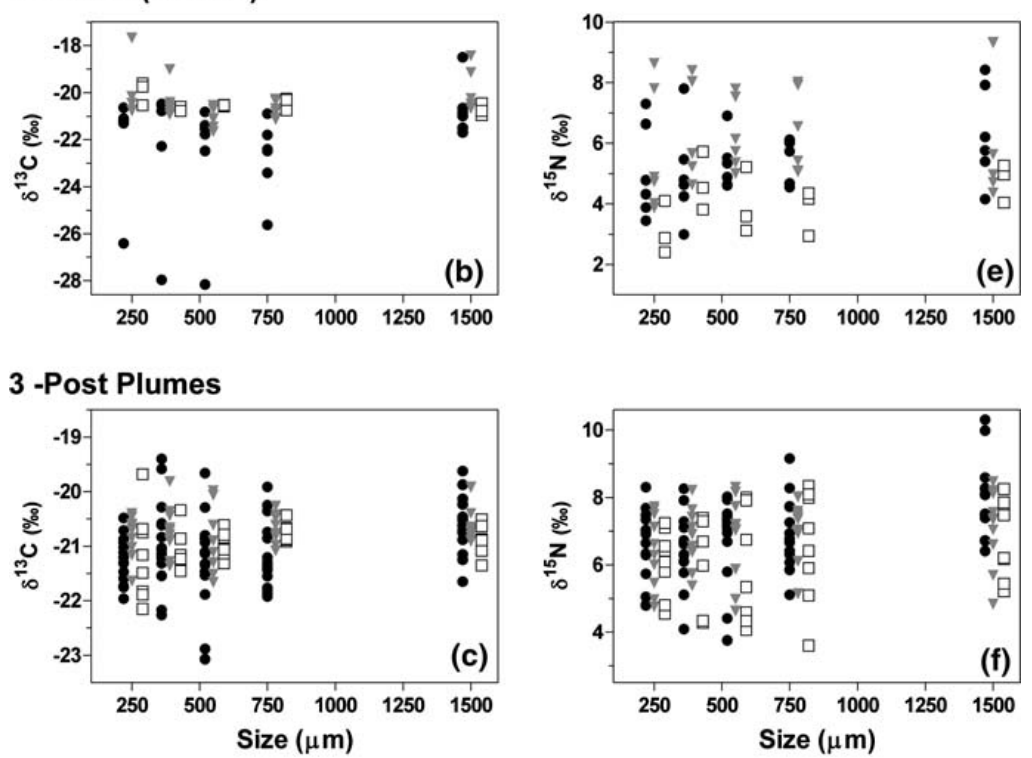

Estuary

$\nabla$ Mouth $\square$ Ocean

Fig. 4 Isotopic differences in carbon (left column) and nitrogen (right column) ratios of zooplankton between the lower estuary, the plume region off the estuarine mouth, and offshore oceanic sites for five size fractions.

Table 3 Proportion of terrestrial and estuarine organic carbon contributing to body carbon of zooplankton consumers, derived from $\delta^{13} \mathrm{C}$ isotope mixing models.

Estuary Plume Region

\begin{tabular}{lcccc} 
Phase & $\overline{\mathrm{x}}$ & $(95 \% \mathrm{Cl})$ & $\overline{\mathrm{x}}$ & $(95 \% \mathrm{Cl})$ \\
\hline 1 - Baseflow & 0.39 & $(0.28-0.50)$ & 0.30 & $(0.17-0.42)$ \\
2 - Events (freshet) & 0.47 & $(0.26-0.67)$ & 0.10 & $(0.00-0.24)$ \\
3 - Post Plume & 0.24 & $(0.13-0.36)$ & 0.17 & $(0.05-0.29)$
\end{tabular}

\section{Discussion}

Zooplankton occupy a key position in the food web architecture and ecosystem energetics of plumes (Dagg et al. 1996; Liu and Dagg 2003; Dagg et al. 2004). Given their significant ecological role in these systems and the nature of plumes as interface regions between terrestrial and marine domains, we asked which energy sources underpin zooplankton in plumes. Conceptually, the two primary sources are marine phytoplankton production stimulated by riverine nutrient loads and direct trophic subsidies via the export of terrestrial 
and estuarine organic matter (Fig. 1). Indubitably, marine phytoplankton was the principal diet of marine zooplankton in nearshore plumes (Figs. 2-4). By contrast, direct assimilation of organic matter from terrestrial and estuarine sources made only a minor contribution to marine consumers in plumes, despite some importance of this material for zooplankton in the lower estuarine reaches. Such low contributions of exported organic matter to zooplankton energetics in nearshore waters are likely the result of three factors: (1) low nutritional quality of exported particles and active discrimination against detritus by selectively-feeding zooplankton, (2) strongly pulsed flows that only create a narrow window of opportunity for consumption confined within limited area, and (3) settling of exported particles to the seafloor below plumes.

Globally, rivers transfer massive amounts $\left(434 \times 10^{6} \mathrm{t} \mathrm{TOC} \mathrm{year}^{-1}\right)$ of terrestrial carbon to coastal seas (Schlünz and Schneider 1999), 46\% of which is in particulate (POC) form (Ludwig et al. 1996); trophic subsidies of marine consumers by this material can therefore be expected. Despite such large carbon fluxes, much less usable carbon may, however, be available to the zooplankton feeding in river plumes. This discrepancy arises mainly because the organic fraction is only $46 \%$ of the total suspended load (Ludwig et al. 1996), and $65 \%$ of the organic particulate matter is refractory (Ittekkot 1988). Thus, terrestrial and estuarine carbon may be highly abundant in turbid river plumes, but it can be of low nutritional quality, consists mainly of refractory carbon, and is masked by suspended sediment.

Zooplankton consume a broad spectrum of particles that differ in size, shape, chemical composition and nutritional quality. An ability to discriminate between particles of high and low quality is energetically advantageous, especially in environments which are dominated by low-quality, suspended matter. Copepods do discriminate successfully between living phytoplankton cells and non-living detritus (Paffenhöfer and Vansant 1985), and such selective feeding appears particularly important in turbid estuarine environments where nonliving matter can comprise the bulk of the suspended matter pool (Tackx et al. 2003). In fact, the nutritional quality of non-living components in suspended particulate matter is low compared with living phytoplankton cells, and this difference in quality has been shown to affect the reproductive success of copepod consumers (Burdloff et al. 2002).

Not only are plumes sites of enhanced phytoplankton biomass and production, but their suspended matter pools also contain a sizeable fraction of non-living food particles (e.g. organic detritus, lithogenic particles) of varying quality and sizes. Although plumes are regarded to offer generally favourable feeding conditions for zooplankton, additions of lithogenic particles and detritus can lower the nutritional value of individual food particles despite higher standing stocks overall (Gaudy et al. 1990; Pagano et al. 1993). Zooplankton consumers are therefore expected to feed selectively on high-quality, fresh phytoplankton production to optimise their energy intake (sensu Tackx et al. 2003). This appears to hold true for some systems, where copepods consume phytoplankton at a higher rate than nonliving particles (Chervin et al. 1981). The dominance of marine phytoplankton as the principal diet of zooplankton in the plume studied by us (Table 4) does concur with a model of selective uptake of living cells and discrimination against detritus exported by river flow. Conversely, zooplankton in other plumes has been reported to have a catholic diet that largely reflects available resources without selective feeding (Turner and Tester 1989).

Grazing by microzooplankton can exceed consumption by larger mesozooplankton, and protozoans in plumes respond rapidly to changes in food supply (Liu and Dagg 2003). Thus, a considerable fraction of pelagic trophic transformations may be channelled through the highly active microbial loop - supported by DOM - rather than mesozooplankton consumers. Thus, if trophic transformations of terrestrial and estuarine organic matter occur mostly via the action of microbes and microzooplankton, incorporation of this material into 
mesozooplankton may have been less readily detectable by us because of isotopic changes and energetic losses in the microbial loop.

Zooplankton can also ingest large quantities of lithogenic particles carried in turbid plume waters, suggesting opportunistic and omnivorous feeding behaviours (Turner 1984). In fact, gelatinous zooplankton can play a key role in the aggregation of fine lithogenic particles, through the packaging of small particles into fecal pellets that sink two orders of magnitude faster (Dagg et al. 1996). Although such enhancement of bentho-pelagic coupling via the feeding activities of plume plankton may be important for the sediment dynamics of plume regions, the negligible carbon and nitrogen content of sediment precludes isotopic tracing of this material in animals, and, in the context of ecosystem energetics, these transformations may be inconsequential.

Small plumes generated by small estuaries are highly dynamic, and their behaviour may not scale down linearly from larger systems (Gaston et al. 2006). The system studied by us was characterised by a strongly pulsed delivery of freshwater that moved as a distinct freshet through the estuary and into the nearshore zone (Fig. 2a). Importantly, such events punctuate longer periods of baseflow conditions where freshwater influence on coastal systems is generally negligible. Small plumes are therefore largely ephemeral features that last from several days to weeks at the most and have a limited spatial ambit (Gaston et al. 2006). The delivery of terrestrial and estuarine organic matter to nearshore regions is erratic and short-lived, and is likely to play only a small role in meeting the longer-term carbon demands of marine consumers.

Suspended particles delivered to nearshore marine waters may sink rapidly out of the surface plumes (Trefry et al. 1994). By contrast, marine phytoplankton production is more likely to be stimulated by dissolved riverine nutrients and therefore persists longer. Thus, the time window for plume zooplankton to consume suspended particles exported from estuaries is short, whereas increased phytoplankton resources are available for longer; the generally low contribution of terrestrial and organic carbon to zooplankton consumers in marine waters found by us may simply reflect limitations to physical availability in the water column from which particles settle to the seafloor below plumes. It follows, therefore, that benthic consumers under and near plumes may derive a greater proportion of their diet from terrestrial sources than their pelagic counterparts. Some evidence exists that terrestrial carbon originally delivered by plumes is incorporated by benthic consumers associated with plume regions (Darnaude 2005), but it remains unknown whether this process has generality or over which spatial and temporal scale it may operate.

\section{Conclusions}

In the small plumes generated by freshwater flows from the Mooloolah estuary, inorganic nutrients stimulate growth of marine phytoplankton, which is the predominant source of carbon for zooplankton consumers. Although terrestrial and estuarine organic matter provides measurable inputs to zooplankton in the lower estuary, it is of little direct nutritional importance to zooplankton in coastal waters. Fluvial carbon is either limited in quantity, too refractory to be assimilated or, more likely, quickly lost to surface waters. The relative importance of nutrient enrichment and direct delivery of organic matter have rarely been separated in studies of plume food webs. Our study demonstrates the utility of stable isotopes in distinguishing these two pathways, although additional, finer resolution among sources might be achieved through the combined use of complementary biomarkers (Bouillon et al. 2008). If the conclusions from the Mooloolah estuary are found to represent plumes from estuaries more generally, the way is open for better informed predictive models of the effects of land-use changes in coastal catchments on food webs in adjacent marine waters. 


\section{Acknowledgements}

Specials thanks to Wendy Barron who braved many a dark, choppy and generally miserable night to help us collect the plankton samples. This project was funded through an Australian Research Council grant (LP0219421) to TAS and RMC in partnership with the Moreton Bay Waterways and Catchments Partnership.

\section{References}

Bouillon S, Connolly RM, Lee SY (2008) Organic matter exchange and cycling in mangrove ecosystems: recent insights from stable isotope studies. J Sea Res 59:44-58

Breed GA, Jackson GA, Richardson TL (2004) Sedimentation, carbon export and food web structure in the Mississippi River plume described by inverse analysis. Mar Ecol Prog Ser 278:35-51

Bunn SE, Davies PM, Winning M (2003) Sources of organic carbon supporting the food web of an arid zone floodplain river. Freshw Biol 48:619-635

Burdloff D, Gasparini S, Villate F, Uriarte I, Cotano U, Sautour B, Etcheber H (2002) Egg production of the copepod Acartia bifilosa in two contrasting European estuaries in relation to seston composition. J Exp Mar Biol Ecol 274:1-17

Chervin MB, Malone TC, Neale PJ (1981) Interactions between suspended organic matter and copepod grazing in the plume of the Hudson River. Estuar Coast Shelf S 13:169-183

Connolly RM, Gorman D, Guest MA (2005) Movement of carbon among estuarine habitats and its assimilation by invertebrates. Oecologia 144:684-691

Dagg M, Benner R, Lohrenz S, Lawrence D (2004) Transformation of dissolved and particulate materials on continental shelves influenced by large rivers: Plume processes. Cont Shelf Res 24:833858

Dagg MJ, Green EP, McKee BA, Ortner PB (1996) Biological removal of fine-grained lithogenic particles from a large river plume. J Mar Res 54:149-160

Dagg MJ, Breed GA (2003) Biological effects of Mississippi River nitrogen on the northern gulf of Mexico - A review and synthesis. J Mar Syst 43:133-152

Darnaude AM, Salen-Picard C, Harmelin-Vivien ML (2004) Depth variation in terrestrial particulate organic matter exploitation by marine coastal benthic communities off the Rhone River delta (NW Mediterranean). Mar Ecol Prog Ser 275:47-57

Darnaude AM (2005) Fish ecology and terrestrial carbon use in coastal areas: Implications for marine fish production. J Animal Ecol 74:864-876

DeNiro MJ, Epstein S (1978) Influence of diet on the distribution of carbon isotops in animals. Geoch Cosm Acta 42:495-506

Fry B (1999) Using stable isotopes to monitor watershed influences on aquatic trophodynamics. Can J Fish Aquat Sci 56:2167-2171

Fry B (2006) Stable isotope ecology, Vol. Springer, New York

Gaston TF, Schlacher TA, Connolly RM (2006) Flood discharges of a small river into open coastal waters: Plume traits and material fate. Estuar Coast Shelf S 69:4-9 
Gaudy R, Pagano M, Lochet F (1990) Zooplankton feeding on seston in the Rhone River plume area (NW Mediterranean Sea) in May 1988. Hydrobiologia 207:241-249

Grall J, Le Loc'h F, Guyonnet B, Riera P (2006) Community structure and food web based on stable isotopes $\left(\delta^{15} \mathrm{~N}\right.$ and $\left.\delta^{13} \mathrm{C}\right)$ analysis of a North Eastern Atlantic maerl bed. $J$ Exp Mar Biol Ecol 338:1-15

Grimes CB, Kingsford MJ (1996) How do riverine plumes of different sizes influence fish larvae: Do they enhance recruitment? Mar Freshw Res 47:191-208

Ittekkot $\vee(1988)$ Global trends in the nature of organic matter in river suspensions. Nature 332:436438

Liu HB, Dagg M (2003) Interactions between nutrients, phytoplankton growth, and micro- and mesozooplankton grazing in the plume of the Mississippi River. Mar Ecol Prog Ser 258:31-42

Lohrenz SE, Fahnenstiel GL, Redalje DG, Lang GA, Dagg MJ, Whitledge TE, Dortch Q (1999) Nutrients, irradiance, and mixing as factors regulating primary production in coastal waters impacted by the Mississippi River plume. Cont Shelf Res 19:1113-1141

Ludwig W, Probst JL, Kempe S (1996) Predicting the oceanic input of organic carbon by continental erosion. Global Biog Cycl 10:23-41

Mallin MA, Cahoon LB, Durako MJ (2005) Contrasting food-web support bases for adjoining riverinfluenced and non-river influenced continental shelf ecosystems. Estuar Coast Shelf S 62:55-62

McClelland JW, Valiela I, Michener RH (1997) Nitrogen-stable isotope signatures in estuarine food webs: A record of increasing urbanization in coastal watersheds. Limnol Ocean 42:930-937

McKee BA, Aller RC, Allison MA, Bianchi TS, Kineke GC (2004) Transport and transformation of dissolved and particulate materials on continental margins influenced by major rivers: Benthic boundary layer and seabed processes. Cont Shelf Res 24:899-926

Milliman JD, Meade RH (1983) World-wide delivery of sediment to the oceans. J Geol 91:1-21

Odum WE, Fisher JS, Pickral JC (1979) Factors controlling the flux of particulate organic carbon from estuarine wetlands. In: Livingston RJ (ed) Ecological processes in coastal and marine systems. Plenum Press, New York, pp 69-80

Paffenhöfer GA, Vansant KB (1985) The feeding response of a marine planktonic copepod to quantity and quality of particles. Mar Ecol Prog Ser 27:55-65

Pagano M, Gaudy R, Thibault D, Lochet F (1993) Vertical migrations and feeding rhythms of mesozooplanktonic organisms in the Rhone River Plume area (North-West Mediterranean-Sea). Estuar Coast Shelf S 37:251-269

Peterson BJ, Fry B (1987) Stable isotopes in ecosystem studies. Annu Rev Ecol Evol Syst 18:293320

Phillips DL, Gregg JW (2001) Uncertainty in source partitioning using stable isotopes. Oecologia 127:171-179

Polis GA, Anderson WB, Holt RD (1997) Toward an integration of landscape and food web ecology: The dynamics of spatially subsidized food webs. Annu Rev Ecol Evol Syst 28:289-316

Polunin NVC, Morales-Nin B, Pawsey WE, Cartes JE, Pinnegar JK, Moranta J (2001) Feeding relationships in Mediterranean bathyal assemblages elucidated by stable nitrogen and carbon isotope data. Mar Ecol Prog Ser 220:13-23 
Schlacher TA, Wooldridge TH (1996) Origin and trophic importance of detritus - evidence from stable isotopes in the benthos of a small, temperate estuary. Oecologia 106:382-388

Schlacher TA, Liddell B, Gaston TF, Schlacher-Hoenlinger M (2005) Fish track wastewater pollution to estuaries. Oecologia 144:570-584

Schlünz B, Schneider RR (1999) Transport of terrestrial organic carbon to the oceans by rivers: Reestimating flux- and burial rates. Int J Earth Sci 88:599-606

Tackx MLM, Herman PJM, Gasparini S, Irigoien X, Billiones R, Daro MH (2003) Selective feeding of Eurytemora affinis (Copepoda, Calanoida) in temperate estuaries: Model and field observations. Estuar Coast Shelf S 56:305-311

Trefry JH, Metz S, Nelsen TA, Trocine RP, Eadie BJ (1994) Transport of Particulate Organic-Carbon by the Mississippi River and Its Fate in the Gulf-of-Mexico. Estuaries 17:839-849

Turner JT (1984) Zooplankton feeding ecology: contents of fecal pellets of the copepods Eucalanus pileatus and Paracalanus quasimodo from continental shelf waters of the Gulf of Mexico. Mar Ecol Prog Ser 15:27-46

Turner JT, Tester PA (1989) Zooplankton feeding ecology: nonselective grazing by the copepods Acartia tonsa Dana, Centropages velificatus De Oliveira, and Eucalanus pileatus Giesbrecht in the plume of the Mississippi River. J Exp Mar Biol Ecol 126:21-43

Wissel B, Fry B (2005) Tracing Mississippi River influences in estuarine food webs of coastal Louisiana. Oecologia 144:659-672

Wysocki LA, Bianchi TS, Powell RT, Reuss N (2006) Spatial variability in the coupling of organic carbon, nutrients, and phytoplankton pigments in surface waters and sediments of the Mississippi River plume. Estuar Coast Shelf S 69:47-63 